\title{
PROFESSIONAL DEVELOPMENT OF THE SPECIALIST \\ IN THE ADULTS EDUCATION SYSTEM : \\ CRITERIA AND LEVELS OF PROFESSIONAL DEVELOPMENT \\ OF THE SPECIALIST IN THE SAMPLE OF DISTRICT (CITY) \\ METHODICAL OFFICE (CENTER)
}

\section{ПРОФЕСІЙНИЙ РОЗВИТОК ФАХІВЦІВ \\ У СИСТЕМІ ОСВІТИ ДОРОСЛИХ: КРИТЕРІЇ \\ ТА РІВНІ ПРОФЕСІЙНОГО РОЗВИТКУ ФАХІВЦІВ \\ НА ВИБІРЦІ МЕТОДИЧНИХ ПРАЦІВНИКІВ РАЙОННИХ (МІСЬКИХ) МЕТОДИЧНИХ КАБІНЕТІВ (ЦЕНТРІВ)}

\section{Tetiana Kravchynska ${ }^{1}$}

DOI: https://doi.org/10.30525/978-9934-588-38-9-6

Abstract. Features of the modern stage of civilization development of humankind, in particular globalization, integration, informatization, fundamentally change the educational paradigm, posing new requirements for the specialist of the new formation, the level of his professionalism and creativity. The declared model of education of the XXI century is education for sustainable development. The philosophical basis is the philosophy of human-centrism and existentialism. This is aimed at training the «network person» (V. Kremen) and explicates in the demanded by society professional qualification and personal characteristics, functional duties, professional qualities and capacity of the specialist, innovative areas (methodological, educational, methodological, organizational-content, etc.) and principles of his professional and pedagogical activity. Modern pedagogical worker is an expression of socio-cultural transformation processes, must meet the requirements of humanitarian, social, scientific and technological progress, have a broad general and professional ideology, a system of professional, moral, spiritual, cultural and national values and ideals, be inculcated in order to be custom-

\footnotetext{
${ }^{1}$ Candidate of Pedagogical Sciences, Associate Professor of the Department of Philosophy and Adult Education,

State Higher Educational Institution «University of Educational Management»

National Academy of Sciences of Ukraine, Ukraine

(C) Tetiana Kravchynska
} 
ized social norm, aspire to continuous professional development throughout life. The current stage of reforming the general secondary education and the requirements imposed on pedagogical workers of district methodical offices, is characterized by significant updating of methodological foundations, strengthening the development of teachers' personal focus on self-education and self-development. The need to understand the complex phenomena of professionalization of the teacher as a dynamic process of development of skill and professionalism is actualized.

Object of research: Professional development of specialist in the adult education system.

Subject of research: determination of criteria and levels of professional development of specialists (on a sample of methodological specialists of the $\mathrm{D}(\mathrm{C}) \mathrm{VO}(\mathrm{C})$.

Purpose of the research: theoretical substantiation and experimental verification of criteria and levels of professional development of specialists (on a sample of methodological specialists of the $\mathrm{D}(\mathrm{C}) \mathrm{VO}(\mathrm{C})$ ).

Objectives of the research:

1. Determination of the stages of professional development of methodologists of the $\mathrm{D}(\mathrm{C}) \mathrm{VO}(\mathrm{C})$.

2. Defining the criteria for the professional development of methodologists of the $\mathrm{D}(\mathrm{C}) \mathrm{VO}(\mathrm{C})$

3 . To determine the indicators of professional development of methodologists of the $\mathrm{D}(\mathrm{C}) \mathrm{VO}(\mathrm{C})$

4. Determination of the levels of professional development of methodological specialists $\mathrm{D}(\mathrm{C}) \mathrm{VO}(\mathrm{C})$.

5. Experimentally check the criteria and levels of professional development of specialists of the $\mathrm{D}(\mathrm{C}) \mathrm{VO}(\mathrm{C})$.

Stages:

Stage I. Determination of the stages of professional development of methodologists of the district methodical offices. To cover the scientific and theoretical achievements concerning the stages of the professional development of methodologists of the $\mathrm{D}(\mathrm{C}) \mathrm{VO}(\mathrm{C})$, outline the position of professional formation and development of teachers at each of the stages of professional development, to generalize the psychological and pedagogical experience of scientific understanding of professional development. The concepts of «professiogenesis», «professional development» and the analy- 
sis of the stages of the professiogenesis of methodologists of district (city) methodical offices (centers) were studied, taking into account the formation of professional installations at each of them.

Stage II. To determine the criteria for the professional development of methodologists of the $\mathrm{D}(\mathrm{C}) \mathrm{VO}(\mathrm{C})$. To identify and substantiate the main criteria for professional development of methodologists of district methodical offices in the process of professional development. The cognitive, praxeological and motivational criteria, which in our opinion most fully reveal the essence of professional development of methodologists of district (city) methodical offices (centers) in the conditions of continuous postgraduate education in the dimension of modern society, are defined and characterized.

Stage III. To determine the indicators of professional development of methodologists of the $\mathrm{D}(\mathrm{C}) \mathrm{VO}(\mathrm{C})$.

Stage IV. Determination of professional development levels of methodological specialists of the $\mathrm{D}(\mathrm{C}) \mathrm{VO}(\mathrm{C})$.

Stage V. Definition of psychodiagnostic methods, conducting of questioning, processing of results, formation of conclusions.

\section{1. Вступ}

Особливості сучасного етапу цивілізаційного розвитку людства, зокрема глобалізація, інтеграція, інформатизація, фундаментально змінюють освітню парадигму, висуваючи нові вимоги до спеціаліста нової формації, рівня його професіоналізму й творчості. Задекларована модель освіти XXI ст. - освіта для стійкого розвитку, філософським підгрунтям якої слугує філософія людиноцентризму й екзистенціоналізму - спрямована на підготовку «мережевої людини» (В. Кремень) та експлікується у затребуваних суспільством професійно-кваліфікаційних та індивідуально-особистісних характеристиках, функціональних обов'язках, професійних якостях, здібностях фахівця, інноваційних напрямах (методологічних, навчально-методичних, організаційно-змістових тощо) і принципах його професійно-педагогічної діяльності. Сьогодні видається недостатнім набутих знань, сформованих умінь i навичок, коли пріоритетного значення набувають адресні й програмно-цільові функціональні інвестиції в людину, іiі творчий, науково-інтелектуальний та інноваційний потенціали, коли за-требувана нова якість професійно-педагогічної дії, високопродуктивний освітній результат. 
Сучасний етап реформування загальної середньої освіти та вимоги які висуваються до педагогічних працівників районних методичних кабінетів, характеризується суттєвим оновленням методологічних засад, посиленням розвитку особистісної спрямованості педагогів на самоосвіту та саморозвиток, відповідно до чого актуалізується потреба у розумінні складних явищ професіоналізації педагога як динамічного процесу розвитку майстерності й професіоналізму. Оскільки на професійний розвиток методистів районних методичних кабінетів впливає безліч об'єктивних факторів (історичних, економічних, політичних тощо), відповідно, необхідно постійне оновлення науково-теоретичного надбання для формування обгрунтованих пропозицій щодо покращення впливу на професійний розвиток і становлення педагогів у системі неперервної післядипломної освіти.

Об'єкт: професійний розвиток фахівців у системі освіти дорослих. Предмет: визначення критеріїв та рівнів професійного розвитку фахівців (на вибірці методичних працівників Р(М)МК(Ц)). Мета: теоретичне обгрунтування та експериментальна перевірка критеріїв та рівнів професійного розвитку фахівців (на вибірці методичних працівників Р(М)МК(Ц)).

Завдання:

1. Визначення етапів професіогенезу методистів районних методичних кабінетів.

2. Визначення критеріїв професійного розвитку методистів $\mathrm{P}(\mathrm{M})$ МК(Ц).

3. Визначити показники професійного розвитку методистів $\mathrm{P}(\mathrm{M})$ МК(Ц).

4. Визначення рівнів професійного розвитку методичних працівників Р(М)МК(Ц).

5. Експериментально перевірити критерії та рівні професійного розвитку фахівців Р(М)МК(Ц).

Етапи:

I етап. Визначення етапів професіогенезу методистів районних методич-них кабінетів. Висвітлити науково-теоретичні здобутки щодо етапів професіогенезу методистів Р(М)МК(Ц), викласти позицію професійного становлення й розвитку педагогів на кожному з етапів професіогенезу, узагальнити психолого-педагогічний досвід наукового 
осмислення професіогенезу. Вивчено поняття «професіогенез», «професійний розвиток» та аналіз етапів професіогенезу методистів районних (міських) методичних кабінетів (центрів) з урахуванням сформованості професійних установок на кожному з них.

II етап. Визначення критерії професійного розвитку методистів Р(М)МК(Ц). Виокремити та обгрунтувати основні критерії професійного розвитку методистів районних методичних кабінетів у процесі професіогенезу. Визначено й охарактеризовано когнітивний, праксеологічний та мотиваційній критерії, які на наш погляд найповніше розкривають сутність професійного розвитку методистів районних (міських) методичних кабінетів (центів) в умовах неперервної післядипломної освіти у вимірі сучасного суспільства.

III етап. Визначення показники професійного розвитку методистів районних (міських) методичних кабінетів (центрів).

IV етап. Визначення рівнів професійного розвитку методичних працівників районних (міських) методичних кабінетів (центрів).

$\mathrm{V}$ етап. Визначення психодіагностичних методик, проведення анкетування, обробка результатів, формування висновків.

\section{2. Етапи професіогенезу методичних працівників Р(М)МК(Ц)}

Розвиток сучасного суспільства призводить до постійного підвищення значимості професій типу «людина-людина», особливо тих 3 них, які мають перетворюючий характер щодо особистості інших, посада методист районного методичного кабінету належить до зазначеного. Саме тому в останні роки активізувалися наукові дослідження в напрямі вивчення проблеми розвитку професійного шляху фахівця.

Це питання стало предметом дослідження багатьох вчених (В. Сластьонін, Н. Кузьміна, В. Шадриков, Е. Зеєр [6], Т. Кудрявцев та інші). Проблему професіогенезу досліджували у своїх працях науковці В. Бодров [1], Л. Мітіна, С. Рогов [21], Т. Траверсе, О. Цільмак [27] тощо.

Дослідники Є. Климов, Г. Кочетов, Б. Ломов розглядають професіоналізацію одним із векторів розвитку особистості, саме як процес становлення фахівця, як ступінь розвиненості професійних якостей [8].

Найбільш вагомої теоретичної цінності вивчення проблеми професійного розвитку особистості набули праці науковців С. Рубінштейна, О. Леонтьева, Б. Ананьєва, К. Альбуханової-Славської, в яких профе- 
сіоналізація розглядається як умова антропогенезу, як засіб розвитку особистості в онтогенезі, як форма її соціалізації [27].

Ю. Поваренков [20] вивчає професіоналізацію як форму соціалізації й індивідуалізації особистості. А. Маркова [15] визначає професіоналізацію однією із сторін соціалізації особистості, саме одним із аспектів іiі розвитку. Таким чином, відповідно до зазначеного, професіогенез відображає механізми процесів соціалізації й індивідуалізації особистості.

Дослідники В. Гордієнко та Л. Копець [4] під професіогенезом розуміють розвиток особистості, зміни та трансформацію ії психологічної структури, які зумовлюються засвоєнням і виконанням професійної діяльності. Зазначаючи, що процес особистісного розвитку і становлення професіонала від початківця до фахівця залежить від історичного розвитку системи професій як соціального інституту, від існуючих освітніх систем, від соціально-економічних умов здійснення професійної діяльності. Розглядаючи поняття професіогенезу, вони виокремлюють:

1) історичний професіогенез (виникнення і розвиток системи професій як соціального інституту і процес формування історичних типів професіоналів);

2) соціально-економічний професіогенез (динаміка професійної діяльності особистості та професійних груп при зміні соціально-економічних умов);

3) інформаційно-технологічний професіогенез (зміни професійної діяль-ності під впливом нових технологій, у тому числі інформаційних);

4) особистісний професіогенез (розвиток особистості як професіонала від моменту самостійного і свідомого вибору професії до творчої самореалізаціі).

Науковець В. Сидоренко [22], вивчаючи професіогенез учителя-словесника в умовах післядипломної освіти, наголошує, що професіогенез - це неперервний процес розвитку особистості, що включає послідовні етапи його становлення, формування, самореалізації і самовдосконалення, зміни у психологічній структурі діяльності, мотиваційній сфері, ціннісних орієнтирах, набуття професійно значущих компетентностей і компетенцій, який зумовлений засвоєнням і реалізацією професійної діяльності в нових соціокультурних умовах. 
О. Кокун [8] зазначає, що для визначення особистісних змін, які відбуваються в процесі засвоєння і здійснення професійної діяльності і зумовлюються характером цієї діяльності, використовують поняття «професіогенезу», яке розглядається як цілісний безперервний процес становлення особистості фахівця, який починається з моменту вибору і прийняття майбутньої професії і закінчується, коли людина припиняє активну трудову діяльність. Виділяючи при цьому наступні напрямки професіогенезу особистості: формування внутрішніх засобів професійної діяльності, що включають спеціальні знання, уміння і навички, мотиваційні аспекти професійної діяльності, професійні риси характеру, здатність до професійного спілкування, рефлексію, інтелектуально-творчі якості, адекватний індивідуальний стиль професійної діяльності; формування та за-своєння зовнішніх (соціальних) засобів професійної діяльності, що супрово-джується накопиченням певних соціальних регуляторів в даному професійному співтоваристві, освоєння соціального простору професії, відповідних матеріалів і інформаційних засобів професійної діяльності. Результатом професіогенезу $€$ досягнутий особистістю рівень професіоналізму, тобто професійної зрілості особистості. Дана характеристика є інтегральним утворенням і включає особистісну, соціальну та діяльнісну зрілість фахівця.

Проаналізувавши визначення професіогенезу дослідників, які займались вивченням розвитку особистості, можна відокремити наступні схожі складові: це процес (В. Бодров [1]), поступовий, планомірний, багатомірний, безперервний процес (Т. Кудрявцев, О. Цільмак [27]); який формує «соціальні якості особистості» (В. Бодров [1], В. Вавілов А. Галактіонов); на основі висококваліфікованої праці і загальнолюдських цінностей (В. Бодров [1], В. Вавілов, А. Галактіонов); його результатом стає досягнення високого рівня професіоналізму (Т. Кудрявцев, О. Цільмак [27]) чи забезпечення професійної діяльності і особистісної ідентичності, яка надає їй цілісності (Г. Яворська), сприяє задоволенню потреб суспільного розвитку (В. Бодров [1], В. Вавілов, А. Галактіонов); охоплює три складові «особистість-діяльність-соціум», які в різній трактовці зустрічаються майже у всіх вищезгаданих визначеннях [1; 8; 27]. Таким чином, узагальнюючи досліджені визначення, професіогенез у широкому смислі набуває наступного трактування - це поступовий, планомірний, багатомірний, 
без-перервний процес досягнення високого рівня професіоналізму, який забезпечує професійну ідентичність, що сприяє цілісності особистості та задоволенню потреб суспільного розвитку у тріаді «особистість-діяльність-соціум».

У більшості авторів поняття «професійний розвиток» вживається в якості синонімічного до поняття «професійне становлення». Тому, під професійним становленням фахівця розуміють процес прогресивної зміни його особистості внаслідок соціальних впливів, професійної діяльності і власної активності, спрямованої на самовдосконалення і саморозвиток. Становлення обов'язково передбачає потребу у розвитку і саморозвитку, можливість і реальність тї задоволення, а також потребу у професійному самозбереженні [6]. Професійне становлення - це формування професійної спрямованості, компетентності, соціально значущих та професійно важливих якостей і їх інтеграція, готовність до постійного професійного зростання, пошук оптимальних прийомів якісного і творчого виконання діяльності у відповідності до індивідуально-психологічних особливостей людини [6].

Професійний розвиток вважається досить складним процесом, що має циклічний характер. Це означає, що людина не тільки удосконалює свої знання, вміння та навички, розвиває професійні здібності, але й може зазнавати й негативного впливу професійної діяльності, який призводить до появи різного роду деформацій і станів, що знижують не тільки її професійні успіхи, але й негативно виявляються й у «поза професійному» житті [9].

Науковець В. Сидоренко [23], вивчаючи професійний розвиток учителя-словесника в системі післядипломної освіти, зазначає, що професійний розвиток - це процес неперервного руху до найвищого професійно-особистісного рівня, який передбачає цілісне та результативне перетворення досвіду шляхом подолання протиріч у професійно-діяльнісній та індивідуально-особистісній сферах, удосконалення педагогічної майстерності протягом усього життя, а вершиною цього, $€$ досягнення найвищого рівня професіогенезу - педагогічної майстерності, акмепрофесіоналізму.

Для вивчення етапів професіогенезу методистів районних методичних кабінетів в умовах неперервної післядипломної освіти будемо спиратися на зазначені етапи професіогенезу за В. Сидоренко [23]: 
1) етап професійної адаптації: актуалізація професійного простору, включення у сферу професійних відношень, опановування нових соціально значущих ролей і функцій, утвердження в педагогічному колективі, формування професійно-особистісної мотивації;

2) етап набуття емпіричного досвіду: акумулюючи досвід, виділяє себе із соціального та професійного середовища, рефлексивно осмислює власну професійну діяльність та вибудовує проект власної педагогічної дії, відбувається актуалізація власних педагогічних здібностей, якостей і можливостей, поведінкових моделей, ціннісних установок, формування професійно значущих компетентностей і компетенцій;

3) етап формування та вдосконалення педагогічної майстерності: удосконалення педагогічної майстерності за індивідуальною траєкторією професійного самотворення і самореалізації;

4) етап творчого самовираження та самореалізації: активно-творча реалізація завдань проекту власного професійного розвитку, продукує на високому рівні професійні знання, уміння, навички, поширює власний перспективний досвід, розробляє ефективний науково-методичний супровід навчально-виховного процесу, систематизує методичні прийоми, форми і методи роботи;

5) етап акмепрофесіоналізму: творча професійна діяльність, інноваційно-експериментальний, проектний підхід до виконання завдань професійного розвитку, становлення і самовдосконалення, виступає представником постійних соціокультурних змін, перспективний педагогічний досвід, авторські педагогічні технології виносить на обласний, міський рівень.

Узагальнення психолого-педагогічного досвіду наукового осмислення професіогенезу, дає підстави розуміти під цим феноменом складний, системний, неперервний процес активної взаємодії особистості та професійного середовища, що забезпечує ефективність професійної педагогічної діяльності та є основою професійного саморозвитку й самовдосконалення фахівця. У професіогенезі методистів районних методичних кабінетів в умовах неперервної післядипломної освіти можна виділити такі етапи: 1) етап професійної адаптації включення у сферу професійних відношень; 2) етап набуття емпіричного досвіду - формування професійно значущих компетентностей i компетенцій; 3) етап формування та вдосконалення педагогічної майс- 
терності - удосконалення педагогічної майстерності; 4) етап творчого самовираження та самореалізації - активно-творча реалізація завдань; 5) етап акмепрофесіоналізму - вершина професійного розвитку.

\section{3. Критерії професійного розвитку методичних працівників Р(М)МК(Ц)}

Українська освіта на сучасному етапі розвитку суспільства зазнає істот-них перевтілень - реформування. Відповідно і вимоги які висуваються до педагогічних працівників районних методичних кабінетів, характеризуються оновленням методологічного змісту, посиленням розвитку професійної спрямованості педагогів на саморозвиток та самоосвіту, педагогічне партнерство й відповідальність.

Але будь-які освітні реформи в результаті стосуються конкретного виконавця - вчителя. Саме методисти районних методичних кабінетів $€$ основною підтримкою вчителів під час реалізації на практиці професійних нововведень. Гарантом ефективної професійної діяльності педагогів $\epsilon$ високий рівень їх професійного розвитку. Тому важливою науково-теоретичною й практичною проблемою $\epsilon$ визначення критеріїв розвитку професійної діяльності педагогів у післядипломній освіті.

Питання післядипломної педагогічної освіти, теорії та практики навчання спеціалістів у системі підвищення кваліфікації стало предметом дослідження багатьох вчених В. Буренко, Л. Гранюк, К. Зарипова, Н. Клокар [9], О. Кокун [8], В. Маслова, В. Олійника [18], Н. Протасової, В. Пуцова та інших.

Критерії професійного розвитку методистів районних методичних кабінетів відображають зміст, структуру, сутність, функції, вимоги до педагогічної діяльності. Зазначимо при цьому, що критерій є засобом, як необхідний інструмент оцінки, але сам не є оцінкою, і може бути виражений через сукупність певних показників [7].

Критерій є ознакою, на основі якої здійснюється оцінка або класифікація чого-небудь. Розроблення й практичне застосування критеріїв - одна з важливих наукових проблем. О. Овчарук зазначає, що «для кожної науки досить важливим $є$ питання про критерії, якими можна керуватися при оцінці педагогічних процесів і явищ. Тільки при наявності таких критеріїв можна зробити висновок про бажані, найкращі результати педагогічного впливу» [17, с. 24]. 
Є. Рогов визначає професіоналізм діяльності як сукупність психофізіологічних, психічних і особистісних змін, що відбуваються в людині у процесі оволодіння і тривалого виконання певного виду діяльності, що забезпечують якісно новий, більш ефективний рівень рішення складних професійних задач в певних умовах [21].

А. Маркова у своїй концепції професіоналізму виокремлює наступні критерії професійного розвитку: об'єктивні критерії вдало вирішує завдання навчання і виховання, готує учнів з бажаними психологічними якостями; суб'єктивні критерії - задоволений професією, мотивований до праці; результативні критерії - досягає бажаних результатів у розвитку особистості учнів; процесуальні критерії - використовує інноваційні способи, технології навчання і виховання; нормативні критерії - засвоює норми професії, досягає майстерності; індивідуально-варіативні критерії - усвідомлює і розвиває свою індивідуальність засобами професії та прагне індивідуалізувати свою працю; критерії наявного рівня - досягає необхідного рівня професійних особистісних якостей, знань і умінь; прогностичні критерії - усвідомлює можливості та зону найближчого професійного розвитку, роблячи все для її реалізації; критерії професійної навченості - відкритий для постійного професійного розвитку, накопичення досвіду; критерії творчості - збагачує досвід професії шляхом особистого творчого внеску; критерії соціальної активності соціально активний; критерії професійної прихильності - відданий педагогічній професії; якісні й кількісні критерії - готовий до якісної і кількісної оцінки своєї праці [15, с. 47].

Професійно-діяльнісний критерій розкривається через гуманістичність, якість професійно-педагогічної дії, професійно-педагогічна компетентність, акмелінгвітична культура, продуктивність професійно-педагогічної діяльності й системність, художньо-педагогічна творчість, інновативність.

Індивідуально-особистісний критерій характеризує професійно важливі й особистісні якості педагога, спеціальні педагогічні здібності, ціннісно-смисловий професійний простір.

Мотиваційно-рефлексивний критерій включає акмеологічність - професійно-фахове й індивідуально-особистісне зростання, неперервне самовдосконалення, самоактуалізація [23]. 
А. Деркач зазначає, що професіоналізм педагогів повинен відповідати певним критеріям, а саме: об'єктивні критерії - ефективність професійної діяльності - навчальної, розвивальної, виховної, діагностичної, корекційної, консультаційної, організаційної, управлінської, самоосвітньої; суб'єктивні критерії - стійка професійна спрямованість, задоволеність працею, розуміння ціннісних орієнтації професії педагога; процесуальні критерії - використання соціально прийнятних, гуманістично спрямованих способів, методів, технологій у своїй діяльності; результативні критерії - досягнення результатів [5].

За дослідженням П. Підкасистого, професійне становлення особистості являє собою складне полисистемне утворення, яке регулюється на основі соціальних та індивідуальних критеріїв. Отже, згідно концепції професійного становлення, виокремлює наступні критерії: соціально і психологічно обгрунтований вибір професії (виникнення і формування професійних намірів); професійне самовизначення (цілеспрямована підготовка до обраної професійної діяльності); високі показники професійної діяльності (активне оволодіння професією); повна реалізація в професійній діяльності (творчість, майстерність) [19].

Відповідно до акмеологічного підходу можна виокремити наступні акмеологічні критерії (міра професіоналізму діяльності, продуктивності діяльності, міра особистісно-професійного розвитку): акмеологічна спрямованість (потреби в досягненнях, мотивація успіху й уникнення невдач, ціннісні орієнтації, спрямованість на справу); акмеологічні знання (повнота, гнучкість, характер засвоєння знань, педагогічна майстерність, професіоналізм); акмеологічні вміння (комунікативні, організаторські, проектування власної педагогічної діяльності, професійно-педагогічне зростання, самовдосконалення); індивідуальнопсихологічні якості (сприяють або заважають просуванню особистості до акме) [5].

Аналіз психолого-педагогічних досліджень 3 даного питання доводить, що проблема професійного розвитку має комплексний характер, тому спираючись на погляди дослідників виокремлюємо когнітивний, праксеологічний та мотиваційний критерії професійного розвитку методистів районних методичних кабінетів.

Когнітивний критерій характеризується професійними знаннями наукового, методичного, психолого-педагогічного, мовленнєвого, 
інформаційного, інноваційного характеру та становлять основу професійного розвитку методистів районних методичних кабінетів у сучасному вимірі.

Праксеологічний критерій включає спеціальні педагогічні здібності, професійно важливі й особистісні якості педагога, уміння, які $є$ складовою частиною професійного розвитку методистів районних методичних кабінетів у системі післядипломної освіти.

Мотиваційний критерій розкриває професійно-фахове й індивідуально-особистісне зростання, неперервне самовдосконалення, самоактуалізацію, формування позитивних мотивів, інтерес до педагогічного процесу.

\section{4. Показники та рівні професійного розвитку методичних працівників Р(М)МК(Ц)}

Показники - це конкретизація виділених критеріїв професійного розвитку методистів районних (міських) методичних кабінетів (центрів) за певними ознаками, що відбивають сучасні навички здійснення професійно-педагогічної діяльності та іiі результативність [24]. Відповідно, критерії й показники визначено й схарактеризовано так, що вони висвічують структурно-функціональні та змістові компоненти процесу професійного розвитку методистів районних (міських) методичних кабінетів (центрів) в системі післядипломної освіти. У свою чергу, зміст критеріїв та показників професійного розвитку методистів районних (міських) методичних кабінетів (центрів) показує динаміку особистості педагога як суб'єкта діяльності, ступінь оволодіння професійним змістом, засобами, методами вирішення професійних завдань.

Узагальнення психолого-педагогічного досвіду дозволило визначити наступні критерії професійного розвитку методистів районних (міських) методичних кабінетів (центрів): когнітивний, праксеологічний, мотиваційний [11]. Відповідно, зазначені критерії характеризуються наступними показниками:

- когнітивний критерій визначається за показниками: професійно-педагогічна компетентність, що передбачає комплексне поєднання грунтовних, систематичних знань, умінь, навичок, професійно-педагогічних ціннісних орієнтацій; продуктивність професійно-педагогічної діяльності; інноваційність, що уможливлює визначення рівня техноло- 
гічної культури, якість упровадження в систему роботи інноваційних підходів, технологій, методів, прийомів та ін.;

- праксеологічний критерій визначається за показниками: сформованість професійного вміння, емоційна стійкість, самоконтроль, самостійність, товариськість, усвідомленість, чутливість тощо;

- мотиваційний критерій визначається за показниками: мотиви, інтереси, ціннісні орієнтації, співвідношення внутрішньої та зовнішньої мотивації, потребі у саморозвитку, самооцінці досягнень, задоволеності своїми досягненнями [23].

Здійснений аналіз відповідної наукової літератури засвідчує, що науковці виділяють різну кількість рівнів професійного розвитку, які характеризуються ступенями прояву показників кожного критерію. Так, більшість визначає високий, достатній, середній та низький рівні, залежно від прояву показників зазначених критеріїв у методичних працівників, можемо стверджувати про сформованість певного рівня професійного розвитку.

На підставі класифікацій, запропонованих В. Безпалько [16], Н. Клокар [9], М. Сідун, Т. Сорочан [25] та ін., визначимо чотири рівні професійного розвитку методичних працівників районних (міських) методичних кабінетів (центрів): 1) репродуктивний; 2) коригувальний; 3) конструкторський; 4) творчий. Окреслимо детальніше сутність кожного рівня.

Творчий (високий) рівень професійного розвитку методистів районних (міських) методичних кабінетів (центрів) за результатами вивчення та аналізу науково-методичної літератури визначається: високим ступенем усвідомлення важливості професійної педагогічної діяльності; високорозвиненими, грунтовними, систематичними знаннями, вміннями, навичками, розвинену інноваційну здатність упроваджувати в систему роботи інноваційні підходи, технології, методи та прийоми; спроможність оцінювати й контролювати власну професійну діяльність для іiі подальшого розвитку, що є показниками визначених когнітивного та праксеологічного критеріїв професійного розвитку методистів районних (міських) методичних кабінетів (центрів).

Конструкторський (достатній) рівень професійного розвитку методистів районних (міських) методичних кабінетів (центрів) розкриває мотиви й цілі професійної підготовки, що дозволяє визначити ваго- 
мість для професійної діяльності; володінням грунтовними та систематизованими знаннями й вмінням їх застосовувати у професійній діяльності; вміннями здійснювати контроль та оцінювання власної професійної діяльності, яка не завжди підлягає коригуванню; частковою готовністю здійснювати творчу та інноваційну діяльність; передбачає сформованість власного професійного досвіду, вмінь презентувати професійну майстерність, гнучкість у використанні педагогічних засобів, прогнозування результатів, оволодіння інноваційними освітніми технологіями.

Для коригувального (середнього) рівня професійного розвитку методистів районних (міських) методичних кабінетів (центрів) властивим є: осмислення мотивів і цілей професійного розвитку не дозволяє визначити їх важливість для професійної діяльності; середнє володіння професійними знаннями, вміннями та навичками; середній рівень комунікативних умінь; недостатня впевненість у власних професійних можливостях; часткова відсутність потреб у подальшому вдосконаленні професійної діяльності.

Для репродуктивного (низького) рівня професійного розвитку методистів районних (міських) методичних кабінетів (центрів) характерним є недостатність інтересу до професійної діяльності; переважанням прагматичних (зовнішніх) мотивів професійної діяльності; низькі оцінювання власної професійної діяльності; відсутність потреб у подальшому професійному вдосконаленні.

\section{5. Психодіагностичне дослідження професійного розвитку методичних працівників Р(М)МК(Ц)}

Важливим чинником ефективного впровадження Концепції «Нова українська школа» виступає високий рівень професійної компетентності методичних працівників, тому значним науковим та практичним питанням є психодіагностичні засади вивчення професійного розвитку методичних працівників районних (міських) методичних кабінетів (центрів).

Наступним етапом нашого дослідження є визначення психодіагностичних методик для вивчення професійного розвитку методичних працівників районних (міських) методичних кабінетів (центрів). При визначенні психодіагностичних методик для вивчення професійного 
розвитку методичних працівників районних (міських) методичних кабінетів (центрів) будемо спиратися на розробки В.В. Сидоренко [23] та розробку колективу спільної лабораторії психології професіоналізму ДЗВО «Університет менеджменту освіти» НАПН України та Рівненського обласного інституту післядипломної педагогічної освіти під науковим керівництвом О. І. Бондарчук [2], а також методики, що вже існують та їх модифікації щодо вивчення професійного розвитку педагогічних працівників.

Отже, відповідні методики діагностики показників професійного розвитку методичних працівників районних (міських) методичних кабінетів (центрів) зазначено в табл. 1.

Таблиця 1

Методична база дослідження показників професійного розвитку методичних працівників районних (міських) методичних кабінетів (центрів)

\begin{tabular}{|c|c|}
\hline $\begin{array}{c}\text { Критерії та показники професійного } \\
\text { розвитку }\end{array}$ & Методики виміру \\
\hline \begin{tabular}{l}
\multicolumn{1}{c}{ Когнітивний } \\
- професійно-педагогічна компетент- \\
ність; \\
- продуктивність професійно-педаго- \\
гічної діяльності; \\
- інноваційність
\end{tabular} & $\begin{array}{l}\text { Методика на визначення рівня профе- } \\
\text { сійної компетентності педагога [23]; } \\
\text { Методика виявлення рівня педагогіч- } \\
\text { ної майстерності [26]; } \\
\text { Методика «Креативний потенціал» [2] }\end{array}$ \\
\hline \begin{tabular}{l}
\multicolumn{1}{c}{ Праксеологічний } \\
- емоційна стійкість; \\
- партнерська взаємодія та професійне \\
спілкування; \\
- емпатія
\end{tabular} & $\begin{array}{l}\text { Методика на визначення рівня емоцій- } \\
\text { ної стабільності і здатності до керу- } \\
\text { вання психічним самопочуттям [23]; } \\
\text { Методика на виявлення стилю взаємо- } \\
\text { дії у професійній діяльності [2]; } \\
\text { Методика на визначення рівня емпатії [21] }\end{array}$ \\
\hline \begin{tabular}{l}
\multicolumn{1}{c}{ Мотиваційний } \\
- інтереси, цінності; \\
- співвідношення внутрішньої та зов- \\
нішньої мотивації; \\
- саморозвиток у професійній дія- \\
льності
\end{tabular} & $\begin{array}{l}\text { Методика М. Рокича «Ціннісні орієн- } \\
\text { тації» [2]; } \\
\text { Методика на визначення рівня мотива- } \\
\text { ції професійно-педагогічної діяльності } \\
\text { [3]; } \\
\text { Методика «Здатність педагога до само- } \\
\text { розвитку» [2] }\end{array}$ \\
\hline
\end{tabular}


Здійснений аналіз наукової літератури дав змогу виокремити вищезазначені психодіагностичні методики, які на нашу думку, якнайповніше розкривають критерії та показники професійного розвитку методичних працівників районних (міських) методичних кабінетів (центрів). Тому, що показники - це конкретизація виділених критеріїв професійного розвитку методичних працівників районних (міських) методичних кабінетів (центрів) за певними ознаками, що відбивають сучасні навички здійснення професійно-педагогічної діяльності та іiі результативність [24]. Відповідно, критерії й показники визначено й схарактеризовано таким чином, що вони висвічують структурно-функціональні та змістові компоненти процесу професійного розвитку методичних працівників районних (міських) методичних кабінетів (центрів) в системі післядипломної освіти. У свою чергу, зміст критеріїв та показників професійного розвитку методичних працівників районних (міських) методичних кабінетів (центрів) показує динаміку особистості педагога як суб'єкта діяльності, ступінь оволодіння професійним змістом, засобами, методами вирішення сучасних професійних завдань [12].

А критеріями професійного розвитку методичних працівників районних методичних кабінетів $\epsilon$, у першу чергу, сформованість відповідних видів компетентностей, мотивація самовдосконалення, результативність виконання фахових завдань, а саме: когнітивний (характеризується науковими, методичними, психолого-педагогічними, мовленнєвими, інформаційними та інноваційними знаннями, необхідними для професійного розвитку методичних працівників районних методичних кабінетів); праксеологічний (що характеризується професійно необхідними вміннями та особистісними якостями методистів районних методичних кабінетів); мотиваційний (розкриває внутрішні та зовнішньо позитивні мотиви участі методичних працівників районних методичних кабінетів у професійній діяльності з постійним підвищення та вдосконаленням свого професійного рівня) [11]. Розуміння закономірностей професійного розвитку є основою розвитку післядипломної педагогічної освіти, визначення змісту, методів для навчання педагогічних працівників не лише з урахуванням стажу, категорії, а й, з урахуванням наявного професіоналізму. 


\section{6. Результати дослідження професійного розвитку методичних працівників Р(М)МК(Ц)}

Опрацювання результатів дослідження здійснювалося з використанням комп'ютерної програми SPSS 20.0 for Windows. Анкетування респондентів дослідження проводилося у 2017-2018 pр. на базі ЦІПО ДЗВО «Університет менеджменту освіти» НАПН України, метою якого було вивчення стану професійного розвитку методичних працівників районних (міських) методичних кабінетів (центрів). У дослідженні брали участь 165 методичних працівників районних (міських) методичних кабінетів (центрів).

Аналіз відповідей, отриманих унаслідок анкетування респондентів, свідчить про те, що проблема професійного розвитку є надзвичайно важливою для методичних працівників районних (міських) методичних кабінетів (центрів). Професійний розвиток сучасних педагогів розглядається як безперервний процес навчання та вдосконалення професійних компетентностей, який дає змогу фахівцеві підтримувати й поліпшувати професійну діяльність відповідно до освітніх викликів, запитів замовників освітніх послуг і ключових стейкхолдерів, при цьому триває впродовж усього періоду професійної діяльності. Це постійний процес вибору й поєднання різних форм, методів, технологій навчання дорослих, які $\epsilon$ найоптимальнішими в конкретній ситуації, у конкретному місці, тощо.

Когнітивний критерій характеризується науковими, методичними, психолого-педагогічними, мовленнєвими, інформаційними й інноваційними знаннями, необхідними для професійного розвитку методистів районних (міських) методичних кабінетів (центрів), і визначається за такими показниками:

- професійно-педагогічна компетентність, що передбачає комплексне поєднання грунтовних, систематичних знань, умінь, навичок, професійно-педагогічних ціннісних орієнтацій (було вивчено за допомогою «Методики визначення рівня професійної компетентності педагога» [23], за результатами якої визначається рівень знань науково-теоретичної бази педагога та рівень його професійної компетентності). Так, 13\% респондентів показали високий рівень професійної компетентності, 58\% - достатній рівень, 28\% - задовільний рівень, а у $1 \%$ респондентів було виявлено критичний рівень знань науково-теоретичної бази й професійної компетентності; 
- продуктивність професійно-педагогічної діяльності, яку було визначено за допомогою «Методики виявлення рівня педагогічної майстерності» [26]. Було виявлено, що 64\% респондентів володіють сучасними методами навчання, професійною майстерністю й упроваджують у систему роботи інноваційні підходи, технології, методи, проводять дослідницьку діяльність, готові до самоосвіти тощо;

- інноваційність, що уможливлює визначення рівня технологічної культури, якість упровадження в систему роботи інноваційних підходів, технологій, методів, прийомів тощо. Для ії вивчення було застосовано методику «Який Ваш креативний потенціал?» [2]. Так, 3\% методичних працівників висококреативні з великим потенціалом, мають здатність надихати до креативності інших, 37\% респондентів мають креативний потенціал достатньо розвинений, який не завжди проявляється, 26\% хороший креативний потенціал, який поки прихований і стримується чи особисто, чи підходом до розв'язання проблем, чи робочим середовищем, а 17\% методичних працівників бракує креативності.

Праксеологічний критерій характеризується професійно необхідними вміннями й особистісними якостями методистів районних (міських) методичних кабінетів (центрів) і визначається за такими показниками:

- емоційна стійкість, яка вивчалася за допомогою «Методики на визначення рівня емоційної стабільності і здатності до керування психічним самопочуттям» [23]. Це дало змогу визначити, що у $62 \%$ респондентів емоційну стабільність сформовано на достатньому рівні, й тільки 11\% мають низьку емоційну стабільність;

- партнерська взаємодія та професійне спілкування, які було визначено за допомогою «Методики на виявлення стилю взаємодії у професійній діяльності» [2]. Відповіді респондентів свідчать про те, що методичні працівники схильні до відповідного стилю взаємодії (24\% методичних працівників схильні до директивного стилю спілкування, $7 \%$ - до невтручання у справи та дії інших людей), 58\% респондентів мають прагнення до взаємодії з людьми, а у 11\% прослідковується пасивність у груповій діяльності;

- емпатія, що вивчалася за допомогою «Методики на визначення рівня емпатії» [21]. Це дало змогу визначити, що відповіді 9\% респондентів не були відвертими, вони прагнули виглядати краще, 
у 17\% респондентів низький та дуже низький рівні емпатійності, вони мають труднощі у встановленні контактів 3 людьми, 52\% респондентів мають нормальний рівень емпатійності, властивий переважній більшості людей, лише $22 \%$ опитаних мають високий та дуже високий рівень емпатійності, вони $\epsilon$ емоційно чуйними, товариськими, швидко встановлюють контакти і знаходять спільну мову, чутливі до потреб і проблем оточуючих.

Мотиваційний критерій розкриває внутрішні та зовнішньо позитивні мотиви участі методистів районних (міських) методичних кабінетів (центрів) у професійній діяльності з постійного підвищення свого професійного рівня й визначається за такими показниками:

- інтереси й цінності, які було визначено за допомогою методики М. Рокича «Ціннісні орієнтації» [2]. Так, як термінальні цінності (тобто цінності, цінні самі по собі (самоцінності), цінності, які не можна обгрунтувати іншими, більш загальними або більш важливими цінностями, до таких цінностей належать: повноцінна любов, щастя, безпека, задоволення, внутрішня гармонія, відчуття завершеності, мудрість тощо), 68\% методичних працівників вважають для себе найбільш значущими фізичне і психічне здоров'я, постійний розвиток (робота над собою, постійне фізичне і духовне вдосконалення), свобода (самостійність, незалежність у судженнях і вчинках), а 53\% респондентів, як інструментальні цінності (цінності-засоби, цінні як засоби, інструменти для досягнення звичайних цілей, як інструментальні цінності зазвичай розглядаються особистісні риси, що допомагають людині в житті: ввічливість, відповідальність, розум, хоробрість, чесність тощо) вважають для себе більш значущими - чесність (правдивість, щирість), терпимість (до поглядів і думок інших, уміння прощати іншим їхні помилки), самоконтроль (стриманість, самодисципліна);

- співвідношення внутрішньої та зовнішньої мотивації, які вивчалося за допомогою методики К. Замфір у модифікації А. Реана «Мотивація професійної діяльності» [3], що дало змогу визначити, що у $38 \%$ респондентів характерним $є$ оптимальний мотиваційний комплекс $\mathrm{BM}>$ ЗПМ > ЗНМ. Цей показник свідчить про те, що найбільш значущим у професійній діяльності для цих методичних працівників $є$ саме зміст виконуваної роботи, прагнення досягнути певних позитивних результатів, прагнення до самовдосконалення. Для 18\% методичних 
працівників характерним є мотиваційний комплекс $\mathrm{BM}>3 П \mathrm{M}=3 \mathrm{HM}$, для якого домінуючим виступає бажання кар'єрного зростання, отримання посади, прагнення отримувати винагороду. Водночас було встановлено, що $31 \%$ досліджуваних відповідає мотиваційний комплекс $\mathrm{BM}>$ ЗПМ < ЗНМ, який свідчить, що при домінуванні внутрішньої мотивації високими залишаються показники зовнішньої мотивації. А 13\% методичних працівників відповідає мотиваційний комплекс $\mathrm{BM}<3 П<$ ЗНМ, для цих педагогів їхня професійна діяльність не $\epsilon$ самоціллю, натомість виступає засобом для досягнення іншої мети і спрямована на кінцевий результат, а не на сам процес її виконання;

- саморозвиток у професійній діяльності було визначено за допомогою методики «Здатність педагога до саморозвитку» [2]. Так, для 23\% методичних працівників характерний високий рівень саморозвитку (готовність до змін і нововведень), 35\% респондентів готові активно використовувати окремі інновації (достатній рівень), а 42\% - мають бажання уникати змін та нововведень.

За підсумками узагальнення отриманих результатів, на основі визначених нами показників респондентів було розподілено на групи за рівнем професійного розвитку. Методичні працівники з творчим (високим) рівнем професійного розвитку (18\%) характеризуються: високим ступенем усвідомлення важливості професійної педагогічної діяльності; високорозвиненими, грунтовними, систематичними знаннями, уміннями, навичками, розвиненою інноваційною здатністю впроваджувати в систему роботи інноваційні підходи, технології, методи та прийоми; спроможністю оцінювати й контролювати власну професійну діяльність для іiї подальшого розвитку, що є показниками визначених когнітивного та праксеологічного критеріїв професійного розвитку методистів районних (міських) методичних кабінетів (центрів).

Для методичних працівників 3 конструкторським (достатнім) рівнем професійного розвитку (31\%) характерним $є$ : володіння грунтовними та систематизованими знаннями й умінням їх застосовувати у професійній діяльності; уміннями здійснювати контроль та оцінювання власної професійної діяльності, яка не завжди підлягає коригуванню; частковою готовністю здійснювати творчу й інноваційну діяльність; передбачає сформованість власного професійного досвіду, умінь презентувати професійну майстерність, гнучкість у викорис- 
танні педагогічних засобів, прогнозування результатів, оволодіння інноваційними освітніми технологіями.

Середній (коригувальний) рівень професійного розвитку, виявлений у $37 \%$ методистів районних (міських) методичних кабінетів (центрів), передбачає середнє володіння професійними знаннями, уміннями та навичками; середній рівень комунікативних умінь; недостатню впевненість у власних професійних можливостях; часткову відсутність потреб у подальшому вдосконаленні професійної діяльності.

Низький рівень професійного розвитку методистів районних (міських) методичних кабінетів (центрів) було виявлено у $14 \%$ респондентів, що характеризується недостатнім інтересом до професійної діяльності; переважанням прагматичних (зовнішніх) мотивів професійної діяльності; низьким оцінюванням власної професійної діяльності; відсутністю потреб у подальшому професійному вдосконаленні.

\section{7. Висновки}

Отже, аналіз отриманих результатів показав, що визначення критеріїв і відповідних їм показників надало можливість окреслити поняття певного рівня сформованості професійного розвитку методистів районних (міських) методичних кабінетів (центрів), яке можна використати під час проведення атестації та сертифікації педагогів, підвищення кваліфікації, професійного саморозвитку педагогів для сприяння безперервному професійному розвиткові в умовах суспільних трансформацій. Сучасний педагогічний працівник має володіти широким загальним і професійним світоглядом, системою професійних, морально-духовних, культурних і національних цінностей, прагнути до неперервного професійного розвитку для впровадження соціально-економічних та освітніх реформ.

Завдяки аналізу результатів проведеного дослідження з'являється також можливість мати уявлення про дієвість професійного розвитку педагогів, яка обумовлюється соціально-економічними й освітніми реформами, що вимагають від фахівців постійного поповнення та поновлення знань, швидкого реагування для якнайшвидшого впровадження цих реформ. Тому є потреба у підготовці висококваліфікованих педагогічних працівників у процесі підвищення кваліфікації, здатних максимально мобілізувати свої професійні можливості для впровад- 
ження найновітніших реформ. Сучасна система підвищення кваліфікації покликана максимально задовольнити професійно-фахові, індивідуально-особистісні, соціокультурні запити замовників освітніх послуг, створити такий диференційований акмеологічний простір, що мотивує до постійної творчої самоактуалізації в професійному й особистісному вимірах за допомогою формальної й інформальної освіти, дає змогу фахівцеві підтримувати й поліпшувати стандарти професійної діяльності і триває впродовж усього періоду його професійно-педагогічної діяльності.

\section{Список літератури:}

1. Бодров В.А. Психология профессиональной деятельности: теоретические и прикладные проблемы. Москва : Ин-т психологии РАН, 2006. 623 с.

2. Бондарчук О.І., Гавлітіна Т.М., Смольська Л.М., Вронська В.М. Комплекс психодіагностичних методик дослідження професіоналізму педагогічних працівників. Київ-Рівне, 2017. 24 с.

3. Бордовская Н.В., Реан А.А. Педагогика : учебник для вузов. СанктПетербург : Издательство «Питер», 2000. 304 с.

4. Гордієнко В.І., Копець Л.В. Основні проблеми дослідження професіогенезу особистості в сучасній психології. Наукові записки. Т. 20. Соціологічні науки. 2002. С. 59-64.

5. Деркач А., Зазыкин В. Акмеология : учебное пособие. Санкт-Петербург : Питер, 2003. 256 c.

6. Зеер Э.Ф. Психология профессий : учеб. пособ. Екатеринбург : УГППУ, 1999. $279 \mathrm{c}$.

7. Карамушка Л.М. Психологія управління : навч. посіб. Київ : Міленіум, 2003. $344 \mathrm{c}$.

8. Кокун О.М. Психологія професійного становлення сучасного фахівця: монографія. Київ : ДП «Інформ.-аналіт. агентство», 2012. 200 с.

9. Клокар Н.I. Інституційний розвиток та професійний розвиток персоналу закладу післядипломної педагогічної освіти : навч.-метод. комплекс. Кн. 2. Київ, 2010. 192 с.

10. Кравчинська Т.С. Етапи професіогенезу методистів районних методичних кабінетів у вимірі сучасного суспільства. Збірник наукових пращь «Педагогічні науки». 2016. Вип. 70. Том 2. С. 66-69.

11. Кравчинська Т.С. Критерії професійного розвитку методистів районних методичних кабінетів у вимірі сучасного суспільства. Освіта дорослих: теорія, досвід, перспективи : зб. наук. пр. Ін-т пед. освіти і освіти дорослих НАПН України. 2016. Вип. 1(12). С. 138-144.

12. Кравчинська Т.С. Показники та рівні професійного розвитку методистів районних (міських) методичних кабінетів (центрів) у вимірі сучасного суспільства. Науковий часопис НПУ імені М.П. Драгоманова. Серія 16. Творча 
особистість учителя: проблеми теорії і практики : збірник наукових праць. 2017. Вип. 29(39). С. 11-14.

13. Кравчинська Т.С. Психодіагностичне дослідження професійного розвитку методичних працівників районних (міських) методичних кабінетів (центрів). Науковий часопис НПУ імені М.П. Драгоманова. Серія : Педагогічні науки: реалії та перспективи. 2018. Вип. 62(5). С. 113-116.

14. Кравчинська Т. Результати дослідження професійного розвитку методичних працівників районних (міських) методичних кабінетів (центрів). Науковий часопис НПУ імені М.П. Драгоманова. Серія 5. Педагогічні науки: реалії та перспективи». 2019. Вип. 70. С. 151-155.

15. Маркова А.К. Психология профессионализма. Москва : Международный центр «Знание», 1996. 308 с.

16. Мартинець Л. Рівні сформованості професійного розвитку вчителів. Педагогічні інновації: ідеї, реалї̈, перспективи. 2016. Вип. 2. С. 75-81.

17. Овчарук О.В. Розвиток компетентнісного підходу : стратегічні орієнтири міжнародної спільноти. Київ : «К.І.С.», 2004. 112 с.

18. Олійник В.В. Післядипломна освіта та безперервний професійний розвиток педагога в умовах реалізації Національної стратегії розвитку освіти в Україні на 2012-2021 роки. Науково-методичне забезпечення діяльності освітніх округів в умовах реформування освітньої галузі : тематична збірка праць. Рівне : ПП Лапсюк, 2012. С. 3-13.

19. Пидкасистый П.И. Психология и педагогика : учеб. пособие. Москва : Издательство Юрайт; ИД Юрайт, 2013. 511 с.

20. Поваренков Ю.П. Психологическое содержание профессионального становления человека. Москва : Изд-во УРАО, 2002. 160 с.

21. Рогов Е.И. Настольная книга практического психолога : в 2 кн. : учеб. пособ. Москва : ВЛАДОС-ПРЕСС. Кн. 2. 2006. 383 с.

22. Сидоренко В.В. Періодизація професіогенезу вчителя української мови і літератури в просторі післядипломної освіти. Наукова скарбниия освіти Донеччини. 2011. № 2(9). С. 82-88.

23. Сидоренко В.В. Теоретичні і методичні засади розвитку педагогічної майстерності вчителя української мови і літератури в системі післядипломної освіти : дис. докт. пед. наук : 13.00.04. Київ, 2013. 486 с.

24. Скрипник M.I. Дослідження проблем професіоналізму науково-педагогічних працівників у андрагогіці. Проблеми освіти. 2015. № 83. Ч. II. C. 194-199.

25. Сорочан Т. Професійна діяльність андрагогів : сучасний погляд. Директор школи, лічею, гімназї. 2008. № 4. С. 27-32.

26. Уруський В.I. Педагогічна діагностика : методичні рекомендації. Тернопіль, 2012. 129 с.

27. Цільмак О.М. Визначення поняття «професіогенез». Професійне становлення особистості : матеріали П'ятої всеукр. наук.-практ. конф., Одеса, 15 лютого 2013 р., 2013. С. 57-60. 


\section{References:}

1. Bodrov V.A. (2006). Psikhologiya professional'noy deyatel'nosti : teoreticheskiye i prikladnyye problemy [Psychology of professional activity: theoretical and applied problems]. Moskva: In-t psikhologii RAN. (in Russian)

2. Bondarchuk O.I., Havlitina T.M., Smol's'ka L.M., \& Vrons'ka V.M. (2017). Kompleks psykhodiahnostychnykh metodyk doslidzhennya profesionalizmu pedahohichnykh pratsivnykiv [A complex of psychodiagnostic methods for the study of professionalism of pedagogical staff]. Kyiv-Rivne. (in Ukrainian)

3. Bordovskaya N.V., \& Rean A.A. (2000). Pedagogika : uchebnik dlya vuzov [Pedagogy: a textbook for high schools]. Sankt-Peterburg : Izdatel'stvo «Piter». (in Russian)

4. Ghordijenko V.I., Kopecj L.V. (2002). Osnovni problemy doslidzhennja profesioghenezu osobystosti $\mathrm{v}$ suchasnij psykhologhiji [The main problems of the study of personality professionalism in modern psychology]. Naukovi zapysky [Proceedings]. Kyiv. T. 20, pp. 59-64.

5. Derkach A., Zazykin V. (2003). Akmeologiy : uchebnoe posobie [Acmeology: study guide]. Sankt-Peterburg : Piter. (in Russian)

6. Zeer E.F. (1999). Psikhologiya professiy : ucheb. posob. [Psychology of professions: textbook. benefits]. Ekaterinburg : UGPPU. (in Russian)

7. Karamushka L.M. (2003). Psykhologhija upravlinnja : navch. posib. [Management Psychology: Educ. tool]. Kyiv: Milenium. (in Ukrainian)

8. Kokun O.M. (2012). Psykhologhija profesijnogho stanovlennja suchasnogho fakhivcja : monoghrafija [Psychology of professional formation of a modern specialist : a monograph]. Kyiv: DP «Inform.-analit. aghentstvo». (in Ukrainian)

9. Klokar N.I. (2010). Instytucijnyj rozvytok ta profesijnyj rozvytok personalu zakladu pisljadyplomnoji pedaghoghichnoji osvity: navch.-metod. kompleks [Institutional development and professional development of staff of the institution of postgraduate pedagogical education: teaching method. complex]. Kyiv. (in Ukrainian)

10. Kravchynska T.S. (2016). Etapy profesioghenezu metodystiv rajonnykh metodychnykh kabinetiv u vymiri suchasnogho suspiljstva. [Stages of professional formation of methodologists of district methodical offices in the dimension of modern society]. Zbirnyk naukovykh pracj «Pedaghoghichni nauky» [Collection of scientific works "Pedagogical Sciences"]. Kherson, pp. 66-69.

11. Kravchynska T.S. (2016). Kryteriyi profesiynoho rozvytku metodystiv rayonnykh metodychnykh kabinetiv u vymiri suchasnoho suspil'stva [Criteria for professional development of methodologists of regional methodical offices in the dimension of modern society]. Osvita doroslykh: teorija, dosvid, perspektyvy: zb. nauk. pr. In-t ped. osvity i osvity doroslykh NAPN Ukrajiny [Adult Education: Theory, Experience, Perspectives: Coll. Sciences. pr. education and adult education of the National Academy of Pedagogical Sciences of Ukraine]. Kyiv, pp. 138-144.

12. Kravchynska T.S. (2017). Pokaznyky ta rivni profesiynoho rozvytku metodystiv rayonnykh (mis'kykh) metodychnykh kabinetiv (tsentriv) u vymiri suchasnoho suspil'stva [Indicators and levels of professional development of methodologists of regional (city) methodical cabinets (centers) in the dimension of modern 
society]. Naukovyj chasopys NPU imeni M.P. Draghomanova [Scientific Chasopys NPU named after M.P. Draghomanova]. Kyiv, pp. 11-14.

13. Kravchynska T.S. (2018). Psykhodiahnostychne doslidzhennya profesiynoho rozvytku metodychnykh pratsivnykiv rayonnykh (mis'kykh) metodychnykh kabinetiv (tsentriv) [Psychodiagnostic study of professional development of methodological workers of district (city) methodical cabinets (centers)]. Naukovyj chasopys NPU imeni M.P. Draghomanova [Scientific Chasopys NPU named after M. P. Draghomanova]. Kyiv, pp. 113-116.

14. Kravchyns'ka T.S. (2019). Rezuljtaty doslidzhennja profesijnogho rozvytku metodychnykh pracivnykiv rajonnykh (misjkykh) metodychnykh kabinetiv (centriv) [The results of the study of the professional development of methodological workers of district (city) methodical offices (centers)]. Naukovyj chasopys NPU imeni M.P. Draghomanova [Scientific Chasopys NPU named after M.P. Draghomanova]. Kyiv, pp. $151-155$.

15. Markova A.K. (1996). Psychology of professionalism [Psychology of Professionalism]. Moskva: Mezhdunarodnyy tsentr «Znanie». (in Russian)

16. Martynecj L. (2016). Rivni sformovanosti profesijnogho rozvytku vchyteliv [Levels of teacher professional development]. Pedaghoghichni innovaciji: ideji, realiji, perspektyvy [Pedagogical innovations: ideas, realities, perspectives]. Kyiv, pp. 75-81.

17. Ovcharuk O.V. (2004). Rozvytok kompetentnisnoho pidkhodu : stratehichni oriientyry mizhnarodnoi spilnoty [Developing a Competency Approach: Strategic Guidelines for the International Community]. Kyiv: «K.I.S.». (in Ukrainian)

18. Oliynyk V.V. (2012). Pisliadyplomna osvita ta bezperervnyi profesiinyi rozvytok pedahoha $\mathrm{v}$ umovakh realizatsii Natsionalnoi stratehii rozvytku osvity $\mathrm{v}$ Ukraini na 2012-2021 roky [Postgraduate Education and Continuing Professional Development of the Teacher in the Conditions of Implementation of the National Strategy for the Development of Education in Ukraine for 2012-2021]. Naukovometodychne zabezpechennia diialnosti osvitnikh okruhiv v umovakh reformuvannia osvitnoi haluzi: tematychna zbirka prats [Scientific and methodological support of the activity of educational districts in the conditions of educational reform: thematic collection of works]. Rivne: PP Lapsiuk, pp. 3-13.

19. Pidkasistyj P.I. (2013). Psikhologiia $i$ pedagogika : ucheb. posobie [Psychology and pedagogy: textbook. allowance]. Moskva: Izdatelstvo Iurait; ID Iurait. (in Russian)

20. Povarenkov Iu.P. (2002). Psikhologicheskoe soderzhanie professionalnogo stanovleniia cheloveka [The psychological content of the professional development of man]. Moskva: Izd-vo URAO. (in Russian)

21. Rogov, Ye.I. (2006). Nastol'naya kniga prakticheskogo psikhologa [Handbook of a Practical Psychologist]. (Vols. 1-2). Moskva: VLADOS-PRESS. (in Russian)

22. Sydorenko V.V. (2011). Periodyzatsiia profesiohenezu vchytelia ukrainskoi movy i literatury $\mathrm{v}$ prostori pisliadyplomnoi osvity [Periodization of the Teacher Genesis of the Ukrainian Language and Literature Teacher in the Area of Postgraduate Education]. Naukova skarbnytsia osvity Donechchyny [The Treasury of Education of Donetsk Region]. Donetsk, pp. 82-88. 
23. Sydorenko V.V. (2013). Teoretychni i metodychni zasady rozvytku pedahohichnoi maisternosti vchytelia ukrainskoi movy i literatury v systemi pisliadyplomnoi osvity [Theoretical and methodological foundations of the development of pedagogical skills of the teacher of Ukrainian language and literature in the system of postgraduate education] (Doctor's Thesis). Kyiv: Instytut osvity doroslykh NAPN Ukrainy.

24. Skrypnyk M.I. (2015). Doslidzhennia problem profesionalizmu naukovo-pedahohichnykh pratsivnykiv $\mathrm{u}$ andrahohitsi [Research of professionalism problems of scientific and pedagogical workers in andragogy]. Problemy osvity [Problems of education]. Kyiv, pp. 194-199.

25. Sorochan T.M. (2008). Profesiina diialnist andrahohiv : suchasnyi pohliad [Professional Activity of Andragogues: A Contemporary View]. Dyrektor shkoly, litseiu, himnazii [Headmaster of the school, lyceum, gymnasium]. Kyiv, pp. 27-32.

26. Uruskyi V.I. (2012). Pedahohichna diahnostyka: metodychni rekomendatsii [Pedagogical diagnostics: guidelines]. Ternopil. (in Ukrainian)

27. Tsilmak O.M. (2013). Vyznachennia poniattia «profesiohenez» [Definition of the term "professiogenesis"]. Proceedings of the Profesiine stanovlennia osobystosti (Ukraina, Odesa, 15 liutoho 2013 r.). Odesa, pp. 57-60. 